\title{
Idea rosyjska a polityka. Konceptualizacja bytu państwowego w koncepcji Piątego Imperium Aleksandra Prochanowa
}

Dalia Sadowska | Akademia Marynarki Wojennej

Słowa kluczowe:

idea rosyjska,

Aleksandr

Prochanow,

Piąte Imperium polityka a kultura, imperializm Russian idea, Alexandr Prokhanov, Fifth Empire, politics and culture, imperialism

\section{Streszczenie}

Artykuł przedstawia relację szeroko pojętej kultury i polityki państwa. Głównym założeniem jest uznanie istnienia związku między takimi kategoriami, jak mentalność lub świadomość społeczna, i funkcjonowaniem, zachowaniami państwa w sferze polityki zarówno wewnętrznej, jak i międzynarodowej, w obrębie jednej cywilizacji. Wobec tego zakłada się, że takie czynniki, jak: położenie geograficzne, historia, kultura, religia, z jednej strony kształtują mentalność społeczeństwa, a z drugiej strony okazują się demiurgiem rzeczywistości, realnie determinującym konkretne działania państwa.

We współczesnej Federacji Rosyjskiej coraz większym zainteresowaniem cieszą się projekty ideologiczne wypływające z ugrupowań o zorientowaniu proimperialnym - jednym z bardziej znaczących jest koncepcja Piątego Imperium autorstwa Aleksandra Prochanowa. Przedstawia on kompleksową wizję państwa, ujmując wszystkie dziedziny jego funkcjonowania. W związku z tym analiza przedstawiona $w$ artykule będzie dotyczyć interpretacji tychże koncepcji w kontekście założeń idei rosyjskiej.

\section{The Russian idea and politics. Conceptualization of state existence} in concept of Fifth Empire by Alexander Prochanov

\section{Summary}

The article presents the relationship of broadly understood culture and state policy. The main assumption is to recognize the relationship between such categories as mentality and state behavior in the sphere of both internal and international politics within one civilization. Therefore, it is assumed that such factors as geographical location, history, culture, religion, on the one hand, shape the mentality of society and on the other hand, they turn out to be a demiurge of reality that really determines the concrete actions of the state.

In the contemporary Russian Federation, ideological projects emerging from pro-imperial oriented groups are becoming more and more popular 
and one of the most significant concepts is the concept of the Fifth Empire by Alexandr Prochanov. It presents a comprehensive vision of the state, including all areas of its functioning. Therefore, the analysis presented below will refer to the interpretation of these concepts in the context of the assumptions of the Russian idea.

\section{Wstęp}

Rozwiązanie problemu imperializmu rosyjskiego wymaga przyjęcia innych niż dotychczas metod. W dyskursie badań nad stosunkami międzynarodowymi coraz częściej docenia się podejście kulturowe. Umożliwia ono przeniesienie swojej perspektywy badań do wnętrza rozpatrywanej kultury, co daje przede wszystkim świadomość kategorii myślowych, jakimi kierują się w swoim działaniu przedstawiciele różnych cywilizacji. Dla badacza stosunków międzynarodowych jest to ważne, ponieważ polityka, stosunki międzynarodowe nie są niczym innym, jak wytworem działalności człowieka, który siłą rzeczy jest istotą zdeterminowaną przez otaczającą go geograficzną, kulturową, historyczną i językową rzeczywistość. Zrozumieć stosunki państw, to zrozumieć charakterystykę ich kultur.

Kultura, pod której pojęciem rozumiemy „,społeczne i intelektualne ukształtowanie jednostki", wraz z jej duchowym oraz materialnym dorobkiem (Julia 2006: 199), stanowi podstawę pojmowania świata przez dane społeczności. Stąd, aby zrozumieć politykę danego kraju, należy przede wszystkim zaznajomić się z kulturą w celu zrozumienia różnych procesów „od wewnątrz". W tym kontekście idea rosyjska może stanowić „klucz" do zrozumienia polityki Federacji Rosyjskiej oraz zachowań na arenie międzynarodowej (Wiśniewski 2012:164).

Idea okazuje się demiurgiem rzeczywistości, a w szerszym kontekście może okazać się podstawą do stworzenia ideologii, którą w swojej polityce może przyjąć państwo.

\section{Istota idei rosyjskiej}

Idea rosyjska, zaraz obok duszy rosyjskiej, stanowi podstawowe pojęcie, jakim należałoby się posłużyć, opisując mentalność społeczną Rosjan. Pojęciem idei rosyjskiej po raz pierwszy posłużył się Fiodor Dostojewski, określając najlepsze cechy zarówno Wschodu, jak i Zachodu, a następnie uległych syntezie i adaptacji w ramach cywilizacji rosyjskiej. Współcześni badacze terminu proponują inne definicje. Andrzej de Lazari zaznacza, że idea rosyjska to nie zwykła koncepcja, obraz Rosji, jak można byłoby domniemać po zrozumieniu samej istoty pojęcia „idei”. To nie projekcja dziejów Rosji zarówno dotychczasowych, jak i jej przyszłych losów. Epitet „rosyjska” jest tu czymś więcej. Rosja to nosicielka idei Boskiej, z misją urzeczywistnienia planów, ikony Boskiej, na całym świecie (Lazari 1995: 34). 
Konkretyzacji terminu idei rosyjskiej podejmuje się również Gracjan Cimek, określając ją jako specyficzne poszukiwanie przez Rosjan odpowiedzi na pytanie, co jest dla ludzi najcenniejsze i najważniejsze. Warto dodać, że owe poszukiwanie jest wzbogacone o aspekt praktyczny, jaki cechuje się działaniem na rzecz realizacji odnalezionych odpowiedzi.

Znamiennym elementem teorii Cimka jest podanie komponentów tzw. składników idei rosyjskiej. Zakłada on istnienie dziewięciu komponentów - wspólnotowości, dobra wspólnego, wolności, duchowości profetycznej, wszechjedności, bogoczłowieczeństwa, doświadczenia integralnego, humanizmu, antropocentryzmu. Jednakże z definicji terminu zaproponowanej przez Andrzeja de Lazari krystalizują się takie cechy, jak misjonizm oraz mesjanizm. Dlatego też poniżej prezentuje się jedenaście składników wraz z dwoma dodatkowymi, będącymi specyficznymi wytworami kultury rosyjskiej, jakimi są kosmizm oraz sofiologia. Są to cechy niezmienne, obiektywnie przypisane do rosyjskiej świadomości społecznej.

Wspólnotowość, czyli inaczej soborowość (od rosyjskiego słowa sobornost'), określa tradycyjny model funkcjonowania rosyjskiego społeczeństwa, ukształtowany zgodnie z nauką Cerkwi prawosławnej. Pierwotną formą była obszczina. Społeczeństwo rosyjskie funkcjonuje jako jeden spójny organizm, w którym każdy osobnik jest zjednoczony z innymi, będąc zarazem wolnym i spontanicznym. Soborowość to jedność pożycia społecznego nieuregulowana żadnymi normami prawnymi. Poprzez wspólną świadomość gwarantuje całkowitą wolność oraz świadomość „kolektywną", jako swoisty wyraz socjalizmu metafizycznego.

Dobro wspólne jest kategorią nadrzędną wobec egoizmu, przeciwstawianą indywidualizmowi, szczególnie wszechobecnemu na Zachodzie. Rosjanin w przeciwieństwie do Amerykanina będzie myślał w większym stopniu o swoim otoczeniu - najbliższych, rodzinie, znajomych - kosztem indywidualnych dążeń, zaspokajania własnych, egoistycznych potrzeb samodoskonalenia się, co jednak nie wyklucza pracy nad samym sobą, która zyskuje wyższy cel, jakim jest właśnie dobro wspólne. Wszelkie działania jednostek mają podłoże altruistyczne (Cimek 2011: 150).

W ramach cywilizacji Zachodu wolność rozumie się zewnętrznie na dwa sposoby. Negatywnie - jako brak wszelkich ograniczeń, a więc "wolność od”, propagowaną m.in. przez liberałów, natomiast pozytywnie - jako taką sytuację, w jakiej każdy robi to, co chce, czyli „,wolność do". IV artykuł Deklaracji Praw Człowieka i Obywatela głosi, że "Wolność polega na tym, by móc robić wszystko to, co nie szkodzi innym" (Julia 2006: 430-434). W rezultacie obu nurtów rozpowszechnia się samowola zorientowana indywidualistycznie, przy czym wszelkie dążenia jednostek ścierają się ze sobą, jednocześnie ograniczając wzajemnie. Stan powstały w wyniku powyższego procesu wymagał stworzenia powszechnego prawa regulującego kwestie związane z obywatelskimi wolnościami i powinnościami. 
W światopoglądzie Rosjan wolność zyskuje charakter wewnętrzny „Prawdziwa wolność jest tylko tam, gdzie Duch Boży [...] Wolność jest tylko wolnością ducha" (K. Aksakow, cyt. za: Lazari 1995: 79). Odzwierciedlenie owego wewnętrznego rozumienia wolności można znaleźć w literaturze - Dostojewski, opisując cierpienia głównego bohatera Zbrodni i kary po dokonaniu zbrodni, pokazuje, jak w momencie naruszenia harmonii kolektywnej wspólnoty Raskolnikow traci wolność - jego dusza ulega moralnemu zniewoleniu (Stołowicz 2008: 182).

Innym elementem współtworzącym ideę rosyjską jest duchowość profetyczna. Rosjanin nie skupia się na rzeczywistości wszechobecnej tu i teraz, ani na przeszłości. Kulturowe istnienie wiary w takie metadoświadczenia, jak paruzja i apokastaza, stanowi imperatyw do wyjścia poza formę w celu poszukiwania właściwej treści, której odnalezienie zapewni czysto transcendentne doświadczenie (Cimek 2011: 138-139). Innymi słowy, profetyzm stanowi przekonanie, że wśród społeczeństwa można wyodrębnić jednostki wyróżniające się w ten sposób, że są one predestynowane do bycia prorokami.

Wszechjedność stanowi kategorię mentalnościową, która determinuje przewagę procesów syntetycznych nad analitycznymi w myśleniu i przez to prowadzącą do szeroko pojętej całościowości. Przykładem jej występowania może być próba teodycei rosyjskiego filozofa Nikołaja Bierdiajewa - czyli usiłowanie uzasadnienia istnienia w świecie stworzonym przez dobrego Boga. Tradycyjna teologia chrześcijańska w Europie wiązała pojawienie się zła, grzechu z wolnością podarowaną człowiekowi przez Boga. W ten sposób Bóg mimo wszystko okazywał się odpowiedzialnym za istnienie zła w świecie, co było paradoksem, gdyż jest on bytem absolutnie dobrym, prawdą, a świat ziemski - nieprawdą. Stąd Bierdiajew wysnuł wniosek, że zło ma swoje źródło nie w Bogu, ani jego działaniach, a w podstawie Boga - Otchłani, z której wypływa i światło, i ciemność. Teoria ta, inspirowana koncepcją Ungrund Boehmego, zakłada, że zło to cień boskiego światła. Są to dwa aspekty, bieguny dokładnie tego samego zjawiska. Ungrund stanowi przedbytową "prawolność" będącą poza zasięgiem Boga, nie rządzi On owym światem, który pochodzi z zewnętrznej ciemności (Stołowicz 2008: 272).

Charakterystyczną dla myśli rosyjskiej koncepcją jest bogoczłowieczeństwo. Jej geneza tkwi w założeniu dwoistości natury Jezusa Chrystusa. Wszechwiedzący Syn Boży niemogący grzeszyć, zamknięty w ludzkim ciele - stanowił niepodzielną jedność. Człowiek poprzez związek z Bogiem może wznieść się na wyżyny deifikacji (Lazari 1995: 12).

Twórcą idei wszechjedności, bogoczłowieczeństwa, profetyzmu oraz sofiologii był Władimir Sołowjow. Te cztery wymienione przeze mnie idee są ściśle ze sobą powiązane. Sofiologia stanowi oryginalny i niepowtarzalny w innych kulturach element cywilizacji rosyjskiej. Powołując się na słowa Tomáša Špidlika, że „[...] sprzecznością terminologiczną byłoby mówić o Rosji i Rosjanach bez Sofii" (cyt. za: Rzeczycka 2002: 17), przybliżę istotę jej fenomenu. 
Sofiologia jest to przede wszystkim doktryna metafizycznego poznania Absolutu poprzez kontemplację jego boskiej hipostazy Sofii. Pod powyższym pojęciem rozumie się również teologię lub mistykę miłości, których oś stanowi koncepcja metafizycznego przekształcenia ludzkości przez miłość (Rzeczycka 2002: 40).

W gnostyckich materiałach Mądrość Boża to jedno z podstawowych pojęć, któremu właściwa jest idea emanacji z Prapoczątku. Powstała hipostaza - Sofia, pełniła rolę pomocnicy Boga w trakcie aktu stworzenia. Zainicjowała stworzenie świata materialnego, świata człowieka, co doprowadziło do rozdzielenia pierwotnej, boskiej jedności - Czystej Jedni. Szaleństwo Sofii i motywy jej działania stanowią praprzyczyny zła. Stąd wynika dychotomia jej istoty - z jednej strony ma charakter boski, doskonały, ale z drugiej strony brzemienny, a przez swój upadek staje się stworzeniem ziemskim. Owe dwie główne hipostazy Sofii to efekt degradacji boskiej pełni (Rzeczycka 2002: 29).

Rosyjską świadomość społeczną od zawsze cechowało silne poczucie kosmosu. Dało to początek prądowi znanemu jako kosmizm. Jednym z ważniejszych prekursorów tej filozofii był Nikołaj Fiodorow. Punktem wyjścia do swoich rozmyślań uczynił filozofię wspólnej sprawy. Dokonał spostrzeżenia, że Ziemia jest wciąż powiększającym się cmentarzyskiem, a największym tragizmem ludzkiej egzystencji jest wymieranie pokoleń. Zainspirowany postępem nauki (zwłaszcza eksperymentem sztucznego wywoływania deszczu za pomocą środków wybuchowych i przywracaniem życia metodą galwanizacji) doszedł do wniosku, że człowiek powinien dążyć do przezwyciężenia śmierci - wskrzeszenia wszystkich zmarłych, którzy w ogóle żyli na Ziemi. Spełnienie owej idei stanowiło szansę na uniknięcie nadejścia Antychrysta i Sądu Ostatecznego w zgodzie z wolą boską. Wskrzeszenie można by było osiągnąć tylko wszystkimi siłami, zdolnościami wszystkich synów ludzkich współpracujących ze sobą. Pomysł ten zrodził problem natury logistycznej, tj. wszyscy wskrzeszeni ludzie w żaden sposób nie pomieściliby się z powrotem na naszej planecie. Stąd wywodzi się idea zasiedlenia całego kosmosu (Stołowicz 2008: 207).

Humanizm w Rosji w większości opiera się na humanizmie europejskim doby oświecenia, który uznaje człowieka za wartość najwyższą. Różnica polega na tym, że w Rosji nie ogranicza się człowieka do istoty racjonalnej. Jednostka ludzka jest dla idei rosyjskiej istotą tajemniczą, której nie da się opisać z pomocą mikroskopu - można stopniowo ją odgadywać (Cimek 2011: 122).

Gracjan Cimek w swoim ujęciu idei rosyjskiej wyodrębnia antropocentryzm jako osobny składnik. Otóż podstawą rosyjskiego antropocentryzmu jest uznanie, że analiza problemów społecznych oraz historiozofii odbywa się zawsze w ramach możliwości epistemologicznych jednostki ludzkiej. To przekonanie, że subiektywizm w analizie historiozoficznej nie jest możliwy do uniknięcia. Ponadto jest to skupienie swych rozważań filozoficznych na problemach związanych z człowiekiem w myśl zasady, że teoria i praktyka są nierozłączne tak samo jak człowiek - mikrokosmos - tworzy spójną całość z całą rzeczywistością - makrokosmosem (Cimek 2011: 123). 
Ostatni składnik idei rosyjskiej wynika po części z poprzednich - doświadczenie integralne, zapewniane przez religię, zapewnia poczucie jedności człowieka z całym światem, rzeczywistością istniejącą wokół (Cimek 2011: 123).

\section{Wpływ Aleksandra Prochanowa na kształtowanie polityki Kremla. Klub Izborski}

Aleksandr Prochanow (ur. 26 lutego 1938 r. w Tbilisi) rozpoczynał swoją karierę jako dziennikarz oraz pisarz sowiecki, teraz także należy do tej grupy politycznych działaczy, których wyróżnia sentyment względem okresu komunizmu w Rosji. Skupia wokół siebie środowisko tzw. czerwono-brunatnych - sojusz ekstremów, którego celem jest stworzenie wspólnego frontu antyliberalnego. Obecnie jest głównym redaktorem radykalnie prawicowej gazety "Zawtra” oraz członkiem sekretariatu Związku Pisarzy Rosji. W Polsce jest znany przede wszystkim z powieści Operacja Heksogen - jedynej wydanej w języku polskim.

Publicysta ma niebagatelny wpływ na kształtowanie polityki Federacji Rosyjskiej. W biografii Prochanowa autorstwa Lwa Daniłkina czytamy, że pisarz często spotyka się z Władisławem Surkowem, który jest notabene współpracownikiem Władimira Putina. Regularnie umawiają się na wspólne obiady, podczas których ideolog przedstawia zapis swoich koncepcji, włączając w to ideę „Piątego Imperium” (aspekt polityczny, ekonomiczny, kulturowy), a następnie Surkow informuje, kiedy projekty znajdą się „na biurku” prezydenta (Daniłkin 2007).

W 2012 r. Prochanow założył think tank zwany Klubem Izborskim ${ }^{19}$ (ros. Изборский клуб). Wraz z pisarzem Klub Izborski zrzesza takich działaczy, jak Aleksandr Dugin, członkami klubu są również fizyk światowej sławy i laureat Nagrody Nobla Żores Ałfiorow oraz archimandryta Tichon Szewkunow - wpływowy hierarcha Rosyjskiej Cerkwi Prawosławnej (Wawrzyńczak 2014: 91).

Idea Klubu Izborskiego zdaniem niektórych komentatorów powstała z inicjatywy Kremla, który w ten sposób stworzył alternatywę wobec think tanków liberalno-demokratycznych. Z początku postrzegano go jako mało poważną inicjatywę, dopiero wydarzenia na Ukrainie na przełomie lat 2012-2013 zmieniły opinie. Ówczesne działania Moskwy, ze szczególnym uwzględnieniem aneksji Krymu i ingerencji na wschodniej Ukrainie, stanowią dowód na sympatyzowane władz z ideami głoszonymi przez Prochanowa i Dugina. Skuteczność forum eksperckiego i sens jego bytu przejawia się w osobach, które zrzesza - tu jako przykład można podać Siergieja Głazjewa, który jest oficjalnym doradcą Władimira Putina (Wawrzyńczak 2014: 92).

${ }^{19}$ Nazwa think tanku jest nieprzypadkowa - Izborsk odgrywa dużą rolę w historiozofii Prochanowa. Nawiązując do Powieści Minionych Lat, za korzenie imperium pisarz uznaje Ruś Kijowską. Jej twórcami byli Truwor, Ruryk i Sineus. Truwor założył gród w okolicach Pskowa (a więc dzisiejszego Izborska). Tam też miała urodzić się Olga, późniejsza żona Igora z dynastii Rurykowiczów (Zob. Wawrzyńczak 2014: 296). 
Głównym motywem powstania grupy jest dążenie do zrzeszenia konserwatywnego i patriotycznego grona eksperckiego w celu przygotowania planu nowej strategii imperialnego rozwoju państwa jako fundamentu nowej, przyszłej ideologii państwowej.

Klub Izborski stanowi środowisko o zorientowaniu antyzachodnim, a ściślej - antyamerykańskim, co w dużej mierze wynika z przekonania, że USA prowadzi politykę antyrosyjską. Towarzysząca „Izborczanom” idea kultu wielkiego zwycięstwa i przygotowań do obrony przed przewidywaną agresją NATO, jak twierdzi Joachim Diec, stanowi kolejną odsłonę imperializmu rosyjskiego (Diec 2010: 147).

Podczas wywiadu z Aleksandrem Wawrzyńczakiem i Grzegorzem Przebindą Prochanow stwierdził:

Teraz nadchodzi czas zmian - politycznych, geostrategicznych, a rewizja granic to nasza bliska przyszłość. Bo jak mogą ewoluować rynki, systemy finansowe, reżimy polityczne i formy istnienia ludzkości, pozostając w poprzednich granicach? Wiele granic wytyczonych po 1991 roku jest po prostu bezsensownych (cyt. za: Wawrzyńczak 2014: 299).

W związku z tym, że po kilku miesiącach jego słowa spełniły się (w postaci aneksji Krymu do Rosji), warto śledzić działalność Prochanowa w celu prognozowania ruchów Federacji Rosyjskiej na arenie międzynarodowej.

\section{Historyczne uwarunkowania i podstawy rozumienia koncepcji Piątego Imperium}

O Piątym Imperium Prochanow wspomniał po raz pierwszy w lutym 2006 r. na łamach tygodnika "Zawtra”, w związku z konfliktem energetycznym między Rosją i Ukrainą. Wówczas Piąte Imperium zdawało się zaledwie zarysem projektu, sama formuła została przez pisarza zastosowana w kontekście upadku Zachodu i szansy na geopolityczną ekspansję Rosji. Charakter ekspansjonistyczny wynikał z głoszenia przez pisarza potrzeby przywrócenia Rosji granic sprzed 1991 r. (Wawrzyńczak 2014: 299).

Dla całościowej interpretacji koncepcji pisarza istotny jest jego sposób pojmowania świata, który może zostać odebrany jako niezgodny z normą - tj. jako przedstawiciela kultury rosyjskiej, słowiańskiej cechuje go odmienne od zachodniego myślenie. Ideolog nie postrzega przeszłości i przyszłości przez pryzmat chwili obecnej i w sposób liniowy, jak to bywa na Zachodzie, a w sposób synchroniczny i integralny (zob. Hampden-Turner i Trompenaars 2002).W związku z tym najważniejsze dla publicysty są pewne konstanty (składniki, elementy stałe), które, mając charakter niezmienny, nie podlegają zniekształceniom w czasie. Dlatego też wszelkie hipostazy bytu rosyjskiego stanowią dla niego jedną, integralną całość i każda z nich jest produktem istnienia i aktywnego oddziaływania konstant (Sieradzan 2010: 306). 
Piąte Imperium to zwieńczenie ogółu poglądów historiozoficznych Prochanowa. Uważa, że specyfika historii Rosji polega na występowaniu triumfów, ale też upokorzeń, które zawsze stanowiły preludium do nowej inkarnacji jej bytu w imperialnej odsłonie. Pisarz przed Piątym Imperium wyróżnia cztery następujące hipostazy państwa rosyjskiego, począwszy od Rusi Kijowskiej - założonej przez Ruryka (wodza Waręgów) w 862 roku, której szczytowy okres przypadł na panowanie Włodzimierza Wielkiego oraz Jarosława Mądrego. Drugi etap stanowi Księstwo Moskiewskie (12131248), na którego okres przypada między innymi okres panowania Iwana IV Groźnego; trzeci - Imperium Rosyjskie (1721-1917), przypadające na rządy dynastii Romanowów, ze szczytowym okresem za panowania Piotra I. Hipostazą poprzedzającą Piąte Imperium jest Związek Socjalistycznych Republik Radzieckich (1922-1991), którego upadek publicysta przeżył nadzwyczaj emocjonalnie. O numeracji stadiów imperialnych publicysta wypowiada się w felietonie Zaczatije wo snie (Sieradzan 2010: 306):

Pierwszym imperium była Ruś Kijowska. Drugim - Księstwo Moskiewskie Rurykowiczów. Trzecim - Białe Księstwo Romanowów. Czwartym - czerwony, Związek Sowiecki. Jesteśmy świadkami narodzin Piątego Imperium. Jest ono jeszcze niewidoczne. Jego poczęcia prawie nikt nie dostrzegł. Dookoła rozlegają się tylko krakania, klekot i zgrzyt. Ale święte poczęcie dokonało się. Tak będziemy obserwować, jak w śniegach i zorzach wzrasta embrion [tłum. własne z jęz. rosyjskiego - D.S.] (Prochanow 2006).

Wawrzyńczak podkreśla, że ideolog, opierając się na Związku Radzieckim okresu stalinowskiego, bagatelizuje totalitarny charakter ówczesnego ustroju. Co prawda nie podważał represji, które miały miejsce (zwłaszcza że dotknęły również jego rodzinę), ale zaniżał ich wartość, zaniżając liczbę ofiar do czterech milionów (Wawrzyńczak 2014: 293).

Jak wskazuje Sieradzan, państwo w myśli Prochanowa będzie potężnym mocarstwem opartym na czterech zasadniczych filarach - silnej, niezależnej władzy, opartej na jak najnowocześniejszych technologiach gospodarce, niepokonanej armii oraz religii, która powinna stanowić podstawę i główny kontekst duchowego rozwoju społeczeństwa. Pisarz widzi bowiem prawosławie w roli primus inter pares - religii narodowej, choć nie odmawia silnej pozycji i mocy decyzyjnej innym konfesjom Rosji (Sieradzan 2010: 308).

\section{Wymiar ekonomiczny Piątego Imperium}

Dla realizacji idei Piątego Imperium istotna jest kwestia gruntownej modernizacji gospodarki, która podczas okresu "smuty" lat dziewięćdziesiątych w znacznym stopniu uległa procesom prywatyzacji, przez co wiele gałęzi przemysłu przestało być pod kontrolą władz państwowych. Państwo musi odzyskać kontrolę nad sektorami, które są strategiczne z punktu widzenia interesu narodowego, a które teraz są przejęte przez oligarchów oraz obcy kapitał. Władze powinny powstrzymać wywóz rosyjskiego 
kapitału za granicę oraz odejść od modelu gospodarki opartego na handlu surowcami, a zwłaszcza ropą naftową.

Rosja zaangażowała się w światowy system wymiany dóbr i usług, co oznaczało jedynie degradację państwa, polegającą na sprowadzeniu go do roli rezerwuaru surowców dla wysoko rozwiniętych państw kapitalistycznych. Dlatego w programie ekonomicznym publicysty ideałem jest model autarkiczny, a więc dążenie państwa do samowystarczalności ekonomicznej. Tenże model gospodarczy zapewniłby Piątemu Imperium odporność na kryzysy regularnie generowane przez światowy system wymiany dóbr i usług. Rosja ma potencjał, aby przekształcić ją w kuźnię najnowocześniejszych technologii (Sieradzan 2010: 310).

Zdaniem Prochanowa Rosja dysponuje wykształconą kadrą pracowniczą i naukową oraz takimi możliwościami, które pozwolą jej na osiągnięcie samowystarczalności zaledwie w ciągu najbliższych 10-15 lat. Odwołuje się do stworzonych przez akademika Dmitrija Siemionowicza Striebkowa komponentów elektrowni słonecznych. Opracowany system zdaniem pisarza przyniesie efekty lepsze od oczekiwanych. Jeśli postawić dwie elektrownie słoneczne tego typu w okolicach Pińska na Białorusi i Uelen (Czukocki Okręg Autonomiczny) z aktywną powierzchnią baterii słonecznych 25/25 km, to do sześciu miesięcy, w okresie od 22 marca do 22 września, pozyskają one energię w ilości 560 mld kWh rocznie. Szczytowa moc każdej elektrowni wyniesie około 125 $\mathrm{mln}$ kWh. Powyższa ilość będzie stanowić około 60\% dostępnej mocy wszystkich elektrowni należących do OAO RAO "JeES Rossii" ${ }^{\prime 20}$.

Ponadto Striebkow zaprojektował system przesyłu energii na długich dystansach, opierając się na odkryciach Nikoli Tesli. Naukowiec eksperymentował z bezprzewodowym przesyłem energii w powietrzu lub pod wodą, co jednak mogłoby prowadzić do katastrofalnych skutków dla środowiska naturalnego. Striebkow posłużył się zasadami sformułowanymi przez słynnego naukowca do opracowania techniki przesyłu mocy na liniach kablowych. Takie przewody są już zamontowane w okolicy Moskwy, działają i przewodzą prąd elektryczny (Prochanow 2007).

Opracowany przez Striebkowa system działa na podstawie rezonansowych metod przesyłu energii na praktycznie nieograniczone odległości, z możliwością przepływu do kilku terawatów. W rezultacie opracowanych metod stworzone możliwości przekraczają potrzeby energetyczne nie tylko Rosji, ale i innych rozwiniętych krajów. Oprócz tego Striebkow bada i pracuje nad aspektami elektrowni słonecznych, jakie postrzega za wadliwe. Odkrył, że nie da się uniknąć negatywnego wpływu czynników atmosferycznych na ostateczną moc energii. Opracowano metody niwelujące ów negatywny proces, jednak są one niemożliwe do zrealizowana ze względów finansowych (Prochanow 2007).

Powołując się na unikalne projekty naukowców nuklearnych z Dubnej i osiągnięcia zespołu Striebkowa, Prochanow dochodzi do wniosku, że Rosja posiądzie unikalną

${ }^{20}$ OAO RAO „JeES Rossii" - państwowa spółka energetyczna, której prezesem jest Anatolij Czubajs. 
energetykę, która zdoła pokryć zapotrzebowania na tanią, nieskończoną i odnawialną energię nie tylko Rosji, ale i wszystkich ludzi na Ziemi (Prochanow 2007).

Jak zauważa Wawrzyńczak, w poglądach Prochanowa na gospodarkę można dostrzec sprzeczności - głosząc jednocześnie potrzebę dążenia do samowystarczalności, stwierdza, że wobec zbliżającego się konfliktu z Zachodem trzeba modernizować przemysł i rolnictwo, w ramach czego uznaje za konieczną współpracę z potencjalnym przeciwnikiem. Tutaj powołuje się na takie przykłady, jak kontrakt z koncernem naftowym British Petroleum, budowę fabryki Volkswagena w Kałudze i kilka pomniejszych projektów (Wawrzyńczak 2014: 302-303).

Pomimo afirmacji stalinizmu pisarz deklaruje się jako zwolennik rozbudowanych świadczeń socjalnych, które byłyby przyznawane obywatelom w zamian za służbę swojemu państwu (Sieradzan 2010: 309).

Ideolog ogłosił, że jedynym kontekstem, w którym Rosja może funkcjonować, jest kontekst imperialny, przy czym, najprawdopodobniej po wizycie w znanym z zagranicznych inwestycji obwodzie kałuskim, sprowadził główną ideę piątej hipostazy do hasła: „westernizacja gospodarki, rusyfikacja kultury” (Wawrzyńczak 2010a). Rosja powinna stać się imperium gospodarczym, czego osiągnięcie zapewni rozwijanie najnowszych technologii, zwłaszcza w zakresie nanotechnologii i biomechaniki. Wiążąc to z afirmacją idei „wskrzeszenia umarłych", nietrudno wywnioskować, że rozwój nauki w tychże kierunkach ukierunkowany jest przede wszystkim na rozszerzanie możliwości ludzkiego organizmu i intelektu (Wawrzyńczak 2010a).

\section{Wymiar polityczny Piątego Imperium}

Prochanow piątą hipostazę określa „imperium sieciowym". Wobec niniejszego modelu kwestia narodowościowa jest istotnym elementem koncepcji państwotwórczej. W kolejnej fazie imperialnej Rosję ma zamieszkiwać wiele nacji, z których każda będzie dysponować możliwością decydowania w kwestiach politycznych (w duchu imperialnego ekumenizmu). Podstawą koegzystowania w pokoju wielu narodów na rozległym terytorium ma być wzajemne poszanowanie kultur, których rozwój będzie jednakowo wspierany. Największe narody zamieszkujące swoje tradycyjne terytoria powinny uzyskać status „narodów tworzących imperium" (cyt. za:Wawrzyńczak 2014: 300). W koncepcji pisarza poza Rosjanami będą to Tatarzy, Baszkirzy, Czeczeni, Czuwasze oraz Jakuci. Każdy z regionów posiadałby część kompetencji administracyjno-politycznych. Z tychże powodów „imperium sieciowe" odpowiadałoby ustrojowi konfederacyjnemu. W przyszłości równoprawnymi centrami Piątego Imperium byłby również Kijów, Mińsk oraz Astana. Czynnikiem konsolidującym naród będzie język i kultura rosyjska (Wawrzyńczak 2014: 300-301).

Jeśli chodzi o system partyjny, podobnie jak zauważyć można w artykułach publikowanych na łamach tygodnika "Zawtra”, Prochanow głosi potrzebę zniesienia 
konwencjonalnych podziałów partii znajdujących się na scenie politycznej na prawicowe i lewicowe na rzecz sojuszu ekstremów - sił antyliberalnych, współpracujących na rzecz realizacji idei imperialnej („imperialny ekumenizm”)(Wawrzyńczak 2014:314).

Nowe rosyjskie imperium będzie się przeciwstawiać zachodniemu liberalizmowi na początku poprzez stopniowe przejmowanie władzy na wszystkich szczeblach przez środowiska patriotyczne. Ponadto konieczna jest zmiana polityki medialnej, bowiem nowe media powinny promować patriotyczny wzorzec społeczny. W miejsce pracownika sektora usług powinien pojawić się wizerunek człowieka pracy. Ważną rolę będzie odgrywać polityka soft power (Wawrzyńczak 2014: 302).

Imperialne ambicje Rosji są zdolni realizować współcześni rosyjscy pasjonariusze. Są to środowiska biznesmenów inwestujących w gospodarkę kraju, rozwijających rodzime technologie i tworzących nowe miejsca pracy, organizacje społeczno-polityczne realizujące idee patriotyczne, a także armia wraz ze służbami specjalnymi, które strzegą bezpieczeństwa państwa. Dużym potencjałem imperialnym dysponują także środowiska twórcze oraz artystyczne (Wawrzyńczak 2014: 304).

\section{Wymiar geopolityczny i polityka zagraniczna Piątego IImperium}

Los państwa rosyjskiego w piątej hipostazie będzie całkowicie zależny od stanu armii rosyjskiej. Przypisywanie istotnej roli odrodzeniu sił zbrojnych u pisarza wynika z jego uczestnictwa we wszystkich istotnych konfliktach zbrojnych Rosji ostatnich czterdziestu lat w roli korespondenta wojennego. Wyszkolona, silna armia jest w stanie bronić nienaruszalności granic imperium i jednocześnie być najważniejszym narzędziem ekspansji terytorialnej, a ponadto jako ważna instytucja społeczna stanowi miejsce krzewienia postaw heroicznych (Wawrzyńczak 2014: 310).

Prochanow stwierdza, że priorytetami nowej imperialnej armii będą obrona magistrali naftowo-gazowych (rurociąg bałtycki) przed sabotażami, ochrona ludności rosyjskiej i rosyjskojęzycznej w byłych republikach radzieckich, jak Estonia, Łotwa, Ukraina lub Kaukaz, a ponadto ochrona przed "agentami wpływu", którzy czynnie działają w ramach rosyjskiej elity zarówno kulturalnej, jak i politycznej (Wawrzyńczak 2010b: 250).

Rosja w piątej hipostazie będzie posiadać, w opinii ideologa, geopolitycznego przeciwnika, co będzie dodatkowym czynnikiem konsolidującym wielonarodowe imperium sieciowe. Rywalizacja z nim toczyłaby się na płaszczyźnie militarnej, ale też kulturowo-cywilizacyjnej (Wawrzyńczak 2014: 301). Owym rywalem są i będą Stany Zjednoczone. Pisarz tłumaczy, że po zwycięstwie nad Związkiem Radzieckim i przyczynieniu się do jego rozpadu USA rozmieściło swoje siły na terytoriach Europy i tam zostało. Wywierany przez nie wpływ na Zachód ma również charakter ideologiczny, promujący wartości demokratyczne i liberalne (Wawrzyńczak 2014: 301).

Konfrontacja z USA jest nieunikniona, jednak nowe imperium rosyjskie powinno prowadzić również aktywny dialog z państwami, które promują własne, konkurencyjne 
względem Moskwy, projekty imperialne. Prochanow wymienia cztery:„,chiński",,,islamski",,europejski” oraz „żydowski”. Warto zauważyć, że wśród nich Rosja nie jest najsilniejszym graczem, bowiem etap imperialny znajduje się dopiero w fazie „zalążkowej" (Wawrzyńczak 2014: 306).

W wymiarze geopolitycznym kluczową rolę będą zatem pełnić dyplomaci rosyjscy. Nowa inkarnacja imperium rosyjskiego rozwija się w niesprzyjającym środowisku międzynarodowym - pozostałe mocarstwa powstałe w ramach wyżej wymienionych projektów za wszelką cenę będą powstrzymywać rozwój rosyjskiego, dlatego dyplomacja będzie musiała być subtelna i nastawiona na wielowektorowość. Niewykluczone, że konieczne okaże się wykorzystywanie sprzeczności między wyżej wymienionymi ośrodkami, unikanie kłótni i wspieranie pozycji najsłabszego gracza. Powstrzymanie osiągnięcia pozycji dominującej przez którąkolwiek ze stron będzie warunkiem zachowania równowagi sił na świecie (Wawrzyńczak 2014: 311).

Celem rosyjskiej polityki zagranicznej jest neutralizacja hegemonii każdego z potencjalnych rywali i dbałość o utrzymanie „wielobiegunowego" świata. Prochanow wskazuje możliwe podmioty, z którymi współdziałanie pomoże w osiągnięciu powyższych celów. W związku z tym proponuje ściślejszą współpracę ze światem islamskim - Iranem oraz palestyńskim Hamasem ${ }^{21}$. Wcześniej z kolei wzywał Kreml do wsparcia Saddama Husajna w ramach konfrontacji z USA i bronił reżimu Baszara Asada w Syrii (Wawrzyńczak 2014: 306).

Wojnę domową w Syrii publicysta postrzega jako wielkie zagrożenie dla Rosji, co dotyczy polityki Zachodu, który w eliminacji reżimu Asada dążył do zabezpieczenia kolejnego przyczółku przed planowaną ekspansją na Kaukaz i w dalszej perspektywie - na Rosję. W takiej sytuacji jedynym właściwym wyborem Rosji powinno być wsparcie dla syryjskiego dyktatora. Pisarz nie ograniczał się jedynie do pustych wezwań, bowiem w 2013 r. wraz z Michaiłem Leontjewem odbył podróż do Syrii i zrelacjonował tamtejszą sytuację (Wawrzyńczak 2014: 306).

Imperializm Prochanowa wyraża się przede wszystkim w militaryzmie, jako narzędziu do obrony i ekspansji, w myśl zasady, że najlepszą obroną jest atak. To dotyczy byłych republik radzieckich, które pisarz nazywa "odciętymi odnóżami imperium, skazanymi na gnicie w oderwaniu od ciała" (cyt. za: Wawrzyńczak 2014: 307). Nie posiadają one zdolności stworzenia trwałego organizmu państwowego, stąd istnieje potrzeba odtworzenia w niedalekiej przyszłości granic terytorialnych z okresu ZSRR - drogą dyplomacji i ekspansji gospodarczej (Wawrzyńczak 2014: 307).

Za skuteczną metodę ekspansji i promocji wartości kultywowanych w ramach cywilizacji rosyjskiej Prochanow uznaje soft power, do którego głównych założeń należy promocja języka oraz kultury rosyjskiej (Wawrzyńczak 2014: 307). Kultura rosyjska jest wyjątkowo literaturocentryczna - stąd polityka "miękkiej siły" powinna opierać się głównie na "eksportowaniu" za granicę literatury rosyjskiej (Wawrzyńczak 2014: 307).

${ }^{21}$ Hamas - Muzułmański Ruch Oporu, organizacja fundamentalistyczna. 
Wawrzyńczak wskazuje, że podczas dwóch rozmów z Prochanowem pytał go o sprawę polską. Pisarz jest świadom, że jego wizje nie tworzą korzystnych scenariuszy dla Polski. Dopóki będzie ona pozostawała w sferze wpływów Zachodu - USA i NATO, dla Rosji pozostanie wrogiem (Wawrzyńczak 2010a).

Według autora koncepcji Piątego Imperium Rosja powinna wyróżniać się ostrożnością wobec zagrożenia ze strony Chin, których armia organizuje manewry, mające na celu ćwiczenie wkraczania na terytoria północne, nawet na odległość tysiąca kilometrów w głąb Syberii. Jednocześnie wyraża się pozytywnie na temat współpracy Rosji z Brazylią, Indiami i Chinami w ramach BRICS (Wawrzyńczak 2010a).

\section{Wymiar ideologiczny Piątego Imperium}

Kształtowanie się wszelkich hipostaz bytu rosyjskiego jest uwarunkowane katalogiem pewnych konstant, które trwają obiektywnie w ramach cywilizacji rosyjskiej. Wobec tego można przyjąć, że za te konstanty Prochanow uznaje wymiary kultury rosyjskiej oraz ideę rosyjską.

Podstawą duchowej sfery funkcjonowania społeczeństwa rosyjskiego jest religia, jako jeden z czterech filarów imperium. Prawosławie, jako religia narodowa, posiada tu wiodącą rolę, jednak równie ważne są inne wyznania tradycyjne dla mieszkańców Rosji islam, buddyzm oraz judaizm (Wawrzyńczak 2014: 305).

W toku swoich ideologicznych rozważań pisarz podkreśla wagę kategorii russkości, jako swoistego charakteru narodowego. Jak podaje Jekaterina Gienadjewna Akimowa, pod tym pojęciem publicysta rozumie fenomen charakterystyczny dla rosyjskiego charakteru, odróżniający tenże naród od innych, antynomię jego wewnętrznego i zewnętrznego życia, dowód przeznaczenia go do pełnienia roli Mesjasza narodów względem innych nacji w procesie dziejowym (szczególnie predestynowania Rosji do realizacji planów boskich na Ziemi). Ponadto russkość, mając ponadczasowy charakter, determinuje często niezrozumiałą dla innych duszę rosyjską i stanowi przyczynę nagromadzonego historycznie cierpienia, i z drugiej strony - nadchodzącego okresu szczęścia (Akimowa 2015: 67).

Prochanow dokonał technokratycznej modyfikacji idei "narodu wybranego". Proroctwa o „wybraństwie narodów" oryginalnie dotyczą Żydów, jednak Prochanow żywi do nich niechęć ${ }^{22}$, głównie ze względów religijno-ideologicznych, bowiem, jak zauważa Wawrzyńczak, traktuje ich jako konkurenta w zakresie idei mesjanistycznej (Wawrzyńczak 2010b: 248):

${ }^{22}$ Zdaniem Wawrzyńczaka niechęć Prochanowa do Żydów stanowi element ubarwiający jego wizerunek. Prochanow nie był zbyt popularny. $Z$ tegoż "nacjonalistycznego getta" wyszedł między innymi dzięki wsparciu żydowskiego kapitału, reprezentowanego przez Borysa Bieriezowskiego, który sfinansował publikację i kampanię reklamową powieści Pan Heksogen - dzięki temu publicysta wrócił do głównego nurtu literatury (Wawrzyńczak 2010b: 249). 
Jestem głęboko przekonany, że Pascha stanowi ideę narodową Rosji. Pascha, rozumiana jak wspólny zryw na rzecz przezwyciężenia śmierci, odrodzenia, wskrzeszenia z martwych, dąży do stworzenia bogoczłowieka. To przekonanie wynika z czytania Pisma Świętego, traktatów z historii rosyjskiej, wierszy rosyjskich i powieści (Prochanow 2006; tłumaczenie własne $z$ jęz. rosyjskiego -D.S.).

Mesjanizm to istotny element projektu imperialnego propagowanego przez pisarza. Misja Rosji sprowadza się do przygotowania „drugiego nadejścia” Zbawiciela. Pogląd ten nie ma charakteru nowatorskiego, bowiem istnieje w myśli Rosji od momentu wybudowania przez patriarchę Nikona w XVII wieku w pobliżu Moskwy Nowej Jerozolimy. Prochanow zauważa, że Żydzi utracili swe wybraństwo dwa tysiące lat temu, nie rozpoznając Chrystusa, a obecnie, kierując się zazdrością, dążą do przeszkodzenia Rosjanom w wypełnieniu ich misji (Wawrzyńczak 2010b: 248).

Trzon poglądów publicysty na prawosławie stanowi filozofia "wspólnego czynu" Nikołaja Fiodorowa. Nie przyjął on jej jednak w oryginalnym kształcie, a dokonał reintepretacji. To, co ideolog wniósł do filozofii Fiodorowa to przemoc i komunizm, do których sam filozof odnosił się bardzo krytycznie (Walicki 2013: 58). Powołując się na bliżej nieokreślone badania rosyjskich naukowców, najprawdopodobniej nawiązuje do grup głoszących ideę transhumanizmu ${ }^{23}$.

Innym, równie istotnym aspektem koncepcji Prochanowa jest pasjonarność. Publicysta definiuje ją jako cud przemieniający naród w Naród - Zwycięzcę, zorganizowaną nację. Pasjonarność towarzyszyła Rosji od zawsze i stanowiła fundament - siłę sprawczą każdej hipostazy imperialnej Rosji (Wawrzyńczak 2014: 303).

Pisarz bagatelizuje zbrodnie okresu stalinowskiego, ofiary ponoszone wśród społeczeństwa są naturalnym stadium rozwoju imperium. Idea państwa jest dla niego nadrzędna względem jednostki ludzkiej. Wzorcem są dla Prochanowa rządy autorytarne, które mogą instrumentalnie traktować jednostkę oraz całe społeczeństwo (Wawrzyńczak 2014: 305). Pogląd ten przybliża działacza do stanowiska realizmu.

Zdaniem publicysty świat upada od ideologii liberalnej i ideologii wolności. Wywołały one ekonomiczne i wojenne katastrofy. Przyczyną upadku jest również ideologia socjalnej sprawiedliwości, ponieważ nie jest ona właściwie dopracowana. Ideologiczną propozycją Prochanowa, nie tylko dla Eurazji, ale i dla całego świata, jest ideologia sprawiedliwości absolutnej. Sprawiedliwość ta nie ma charakteru socjalnego, a reguluje stosunki nie tylko człowieka z człowiekiem, ale i człowieczeństwa ze światem, a nawet z planetami układu słonecznego (Tatilia 2012) ${ }^{24}$.

\footnotetext{
${ }^{23}$ Transhumanizm - nurt filozoficzno-światopoglądowy głoszący, że dzięki rozwojowi nauki i nowoczesnych technologii w przyszłości będzie możliwe przedłużanie wieku ludzkiego, eliminacja chorób i cierpienia, i wreszcie - pokonanie śmierci. Wawrzyńczak wymienia tu założoną w 2005 r. grupę Rosyjski Ruch Transhumanistyczny (ros. Российское Трансгуманистическое Движение), której to głównym celem jest badanie możliwości przedłużania życia ludzkiego organizmu i w dalszej perspektywie - nieśmiertelności (Wawrzyńczak 2014: 308).

${ }^{24}$ Taki pogląd pozostaje w ścisłym związku z kosmizmem Fiodorowa. Człowiek za swojego życia jest odpowiedzialny za przywrócenie do życia tych, którzy już umarli. Jezus Chrystus poprzez
} 


\section{Zakończenie}

Po niepowodzeniu projektu liberalnego w Federacji Rosyjskiej coraz większe znaczenie zyskuje środowisko proimperialne. Jedną z najważniejszych koncepcji, która z niego wypłynęła, jest Piąte Imperium autorstwa działacza politycznego, pisarza i publicysty - Aleksandra Prochanowa. Powodzenie owego projektu, zainteresowanie nim przez władze Federacji Rosyjskiej oraz rosnące znaczenie think tanku Klub Izborski dowodzi słuszności stwierdzenia, że Rosja poszukuje swojego rozwiązania ustrojowego i już znalazła ku niemu drogę. Jest świadoma swej specyfiki cywilizacyjnej, która determinuje wybór rozwiązań systemowych. W związku z tym Piąte Imperium oparte na specyfice rosyjskiej kultury i wartościach dla Rosjan najważniejszych - czyli przedstawionej w tym artykule idei rosyjskiej - poprzez swoją adekwatność wywarło znaczący wpływ zarówno na społeczeństwo, jak i warstwę rządzącą. Podkreślając rezonans koncepcji, należy zaznaczyć, że Prochanow stworzył szkic, nad którym pracuje teraz wielu ideologów.

\section{Bibliografia}

\section{Źródła w języku polskim}

Bierdiajew N., 1999, Rosyjska Idea, Warszawa: Stowarzyszenie Kulturalne Fronda.

Cimek G., 2011, Rosja - Państwo Imperialne?, Gdynia: AMW.

Diec J., 2015, Geostrategiczny wybór Rosji u zarania trzeciego tysiąclecia. Doktryna rosyjskiej polityki zagranicznej. Partnerzy najbliższi i najdalsi, t. 1, Kraków: UJ.

Fiodorow N., 2012, Filozofia wspólnego czynu, tłum. M. Milczarek, C. Wodziński, Kęty: Wydawnictwo Marek Derewiecki.

Jędryśko C., 2013, Wizjoner, prorok czy szaleniec? Rozważania wokół filozofii wspólnego czynu Nikołaja Fiodorowa, „Estetyka i Krytyka”, 2(29)/2013, Kraków, UJ, https://depot.ceon.pl/bitstream/handle/123456789/6306/J\%20drysko_Cezar.pdf?sequence=1 [dostęp: 5.08.2018].

Hampden-Turner Ch., Trompenaars F., 2002, Siedem wymiarów kultury. Znaczenie różnic kulturowych w działalności gospodarczej, Kraków: Oficyna Ekonomiczna.

Julia D., 2006, Słownik Filozofii, Katowice: Książnica.

Karpiński A., Kojkoł J., 2002, Filozofia. Zarys historii, Gdynia: AMW.

Lazari A. de, 1995, Mentalność Rosyjska - Słownik, Katowice: Wydawnictwo Śląsk.

Rzeczycka M., 2002, Fenomen Sofii - Wiecznej Kobiecości w prozie powieściowej symbolistów rosyjskich (Andrieja Biełego, Fiodora Sołoguba i Walerija Briusowa), Gdańsk: UG.

wskrzeszenie Łazarza, a następnie własne zmartwychwstanie nadał ludzkości właśnie taki cel powszechne wskrzeszenie. Myślenie „moskiewskiego Sokratesa" cechowały przede wszystkim: maksymalizm, holizm, absolutny prymat powinności nad bytem, radykalny imperatyw działania oraz antysystemowość; są to cechy także filozofii Prochanowa. Ideolog, jako socjalista, jest zwolennikiem braterstwa oraz organizacji społeczeństwa na zasadach wspólnotowości. Taki pogląd ma korzenie religijne-chrześcijańskie, dokładnie tak jak w przypadku Fiodorowa (Fiodorow 2012). 
Obolevitch S.T., 2007, Między naukq a metafizykq̨: filozofia rosyjskiego kosmizmu, ,',Semina Scientarium" $\mathrm{nr}$ 6, http://seminascientiarum.wdfiles.com/local-files/numer-6-2007/6.4.Obolevitch.pdf [dostęp: 4.05.2017].

Sieradzan P.J., 2010, Czerwono-Brunatni. Sojusz radykalizmu lewicy i prawicy w Rosji współczesnej, Warszawa: Aspra-Jr.

Sieradzan P.J., 2015, Ideologia państwowa współczesnej Białorusi [w:] Domagała M., Piskorski M., Sieradzan P.J., Szołucha M., Białoruś: model państwa i gospodarki, Warszawa: Stowarzyszenie Europejskie Centrum Analiz Geopolitycznych.

Stołowicz L., 2008, Historia Filozofii Rosyjskiej. Podręcznik, Gdańsk: słowo/obraz terytoria.

Tatarkiewicz W., 1970, Historia Filozofii, t. 1, Warszawa: PWN.

Walicki A., 2013, Od projektu komunistycznego do neoliberalnej utopii, Kraków: Universitas Polska Akademia Nauk.

Wawrzyńczak A., 2014, Imperialista, technokrata, mistyk: Twórczość literacka i publicystyczna Aleksandra Prochanowa, Kraków: scriptum.

Wawrzyńczak A., 2010a, Marzenia o „piątym imperium ",,Znak" nr 659, http://www.miesiecznik.znak. com.pl/6592010aleksander-wawrzynczakmarzenia-o-piatym-imperium/ [dostęp: 7.05.2017].

Wawrzyńczak A., 2010b, Projekt polityczny czy kreacja literacka? Idea Piq̨tego imperium Aleksandra Prochanowa [w:] Pochwała różnorodności. Księga ofiarowana dr hab. Annie Gildner, prof. UJ, red. H. Waszkielewicz, Collegium Columbinum, Kraków, seria ROSJA *myśl*słowo*obraz.

Wiśniewski R., 2012, Kultura strategiczna, czyli o kulturowych uwarunkowaniach polityki zagranicznej i bezpieczeństwa, „Przegląd Strategiczny" nr 1, http://studiastrategiczne.amu.edu.pl/wp-content/ uploads/2013/03/13.WISNIEWSKI.pdf [dostęp: 3.05.2017)].

Włodkowska-Bagan A., 2012, Soft power w polityce zagranicznej Federacji Rosyjskiej wobec państw „BliskiejZagranicy", cejsh.icm.edu.pl/.../Wlodkowska-Bagan-A.-Soft-Power-w-polityce-zagranicznej. pdf [dostęp: 3.05.2017].

Wodziński C., 2005, Trans, Dostojewski, Rosja, czyli o filozofowaniu siekierq, Gdańsk: słowo/obraz terytoria.

\section{Źródła w języku rosyjskim}

Акимова Е.Г., 2015, Русская идея Александра Проханова в зеркале фразеологии, „Вестник Новгородского Государственного Университета", № 1 (84), http://cyberleninka.ru/article/n/ russkaya-ideya-aleksandra-prohanova-v-zerkale-frazeologii [dostęp: 4.05.2017].

Данилкин Л., 2007, Человек с яйцом. Жизнь и мнения Александра Проханова, Moskwa, Ad Marginem, http://ru-prokhanov.livejournal.com/223442.html [dostęp: 1.05.2017].

Проханов А., 2016, Донбасс и Русская идея, wypowiedź, https://www.youtube.com/watch?v=vXm07HMbTEO [dostęp: 5.05.2017].

Проханов А., 2007, Свой - Чужой, Москва: Алгоритм.

Проханов А., 2004, Симфония „Пятой Империи", http://www.libros.am/book/read/id/159398/slug/ simfoniya-pyatojj-imperii [dostęp: 28.04.2017].

Проханов А., 2007, Технологии "Пятой Империи", http://read24.ru/read/aleksandr-prokhanov-tehnologii-pyatoy-imperii [dostęp: 12.01.2015].

Татиля К., 2012, Александ Проханов: Такая русская идея, понимаемая метафизический, может быть близка и казахам, https://camonitor.kz/4572-.html [dostęp: 7.05.2017]. 